\title{
The Role of Polyribosomes in the Biosynthesis of Glycoprotein
}

\author{
By G. B. RobINson \\ Department of Biochemistry, University of Oxford, OX $13 Q U$
}

(Received 3 October 1969)

In an attempt to resolve the controversy about the significance of ribosomal labelling observed to occur in liver after administration of [ $\left.{ }^{14} \mathrm{C}\right]$ glucosamine, Molnar \& Sy (1967) reported experiments showing that puromycin promoted the release of glucosamine-labelled protein from rat liver polyribosomes; they concluded that their results demonstrated the presence of glucosamine-labelled nascent protein in the ribosomes. It has since been established that rat liver polyribosome preparations can be contaminated by $\left[{ }^{14} \mathrm{C}\right]$ glucosamine-labelled protein that is not ribosomal in origin (Robinson, 1969), and no evidence is available to confirm or refute the possibility that puromycin might effect the release of this contaminating protein. These considerations made interpretation of the results of Molnar \& Sy (1967) uncertain. Consequently the effect of puromycin has now been studied with a glucosamine-labelled polyribosome fraction that showed little evidence of contamination by extraneous protein ('packed' polyribosomes; Robinson, 1969).

'Packed' polyribosomes were prepared as described (Robinson, 1969) from the livers of rats

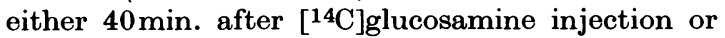

$4 \mathrm{~min}$. after $\left[{ }^{14} \mathrm{C}\right]$ leucine injection, since at these times ribosomal radioactivity was at a maximum (Molnar, Robinson \& Winzler, 1965). The polyribosomes were incubated with supernatant enzyme and energy sources in the presence or absence of puromycin (Traut \& Monro, 1964); they were separated from the incubated mixture by centrifugation, precipitated with trichloroacetic acid and, after being washed, were analysed for their protein, RNA and radioactivity contents (Robinson, 1969). For both labelled compounds the presence of puromycin resulted in a doubling of the amount of radioactivity released from the ribosomes as compared with the release occurring in the absence of the drug (Table 1). This difference was not due to breakdown of the ribosomes during incubation, since recoveries of RNA and protein in the ribosomal pellets was the same as that found in control incubations containing only polyribosomes and supernatant enzyme. The radioactivity released during the incubations could be almost completely recovered from the supernatant as trichloroacetic acid-insoluble material. In separate experiments 'packed' polyribosomes from rats injected with [14C]glucosamine were subjected to hydrolysis in

Table 1. Recovery of radioactivity and $R N A$ in rat liver polyribosomes after incubation in the presence and absence of puromycin

'Packed' polyribosomes were prepared from livers taken from rats 4 min. after injection with L-[1.14C]leucine $(8 \mu \mathrm{C})$ or $40 \mathrm{~min}$. after injection with $\mathrm{D}-\left[1{ }^{14} \mathrm{C}\right]$ glucosamine $(8 \mu \mathrm{C})$ (Robinson, 1969). The total polyribosomes were suspended in $7 \mathrm{ml}$. of $0.15 \mathrm{M}$-sucrose containing tris- $\mathrm{HCl}$ buffer, $\mathrm{pH} 7.4(30 \mathrm{mM}), \mathrm{KCl}(80 \mathrm{mM})$ and $\mathrm{MgCl}_{2}$ $(6 \cdot 2 \mathrm{mM})$. Samples $(2 \mathrm{ml}$.) of polyribosomes were incubated with $2 \cdot 0 \mathrm{ml}$. of $0 \cdot 15 \mathrm{M}$-sucrose (as above) containing $0.3 \mathrm{ml}$. of supernatant enzyme, 2-mercaptoethanol (30 $\mu \mathrm{moles})$, ATP ( $3 \mu \mathrm{moles})$, GTP (1.5 $\mu$ moles), phosphoenolpyruvate $(30 \mu \mathrm{moles})$, pyruvate kinase $(30 \mu \mathrm{g}$.) and puromycin $(3 \mu \mathrm{moles})$. Supernatant enzyme was prepared from unlabelled rat liver homogenized in $0.25 \mathrm{M}$-sucrose and centrifuged at $150000 \mathrm{~g}_{\mathrm{av}}$. for $60 \mathrm{~min}$. Control samples of polyribosomes were incubated with supernatant enzyme only. Incubation was stopped by the addition of $7 \mathrm{ml}$. of chilled $0 \cdot 15 \mathrm{M}$-sucrose containing no $\mathrm{KCl}$. The resulting suspensions were centrifuged at $150000 \mathrm{~g}_{\mathrm{av}}$. for $60 \mathrm{~min}$. to sediment the ribosomes, which were analysed for protein, RNA and radioactivity as described (Robinson, 1969). The results are from five experiments \pm s.D., and are expressed as percentage recoveries compared with the control incubation. Average ribosomal specific radioactivities were 250 d.p.m./mg. of RNA with [14C]glucosamine and 950d.p.m./mg. of RNA with [ $\left.{ }^{14} \mathrm{C}\right]$ leucine.

\begin{tabular}{|c|c|c|c|c|}
\hline \multirow[b]{2}{*}{$\begin{array}{l}\text { Labelled } \\
\text { compound }\end{array}$} & \multicolumn{2}{|c|}{$\begin{array}{c}\text { Recovery of } \\
\text { radioactivity (\%) }\end{array}$} & \multicolumn{2}{|c|}{$\begin{array}{c}\text { Recovery of } \\
\text { RNA (\%) }\end{array}$} \\
\hline & $\begin{array}{c}\text { With } \\
\text { puromycin }\end{array}$ & $\begin{array}{l}\text { Without } \\
\text { puromycin }\end{array}$ & $\begin{array}{c}\text { With } \\
\text { puromycin }\end{array}$ & $\begin{array}{l}\text { Without } \\
\text { puromycin }\end{array}$ \\
\hline $\begin{array}{l}{\left[{ }^{14} \mathrm{C}\right] \text { Leucine }} \\
{\left[{ }^{14} \mathrm{C}\right] \text { Glucosamine }}\end{array}$ & $\begin{array}{l}54 \cdot 4 \pm 3.9 \\
58 \cdot 8 \pm 10 \cdot 5\end{array}$ & $\begin{array}{l}76 \cdot 4 \pm 11 \cdot 5 \\
80 \cdot 1 \pm 6 \cdot 0\end{array}$ & $\begin{array}{c}103 \pm 12.5 \\
97 \cdot 4 \pm 11 \cdot 8\end{array}$ & $\begin{array}{r}98 \cdot 6 \pm 13 \cdot 7 \\
101 \pm 8 \cdot 9\end{array}$ \\
\hline
\end{tabular}


$3 \mathrm{M}-\mathrm{HCl}$ at $100^{\circ}$ for $4 \mathrm{hr}$. Approx. $85 \%$ of the radioactive material was released in acid-soluble form during hydrolysis and was identified as glucosamine by paper chromatography (Robinson, 1968).

It has been established that the radioactivity found in 'packed' polyribosome preparations from rats injected with $\left[{ }^{14} \mathrm{C}\right]$ glucosamine was not a consequence of contamination (Robinson, 1969). The present study shows that this radioactivity was due to the presence of $\left[{ }^{14} \mathrm{C}\right]$ glucosamine bound to trichloroacetic acid-insoluble material that could be partly released from the ribosomes on incubation with energy sources and supernatant enzyme; the release of this material was doubled when puromycin was added to the incubation medium. Further, these results are comparable with those obtained in control experiments with polyribosomes obtained from rat liver shortly after injection with [ $\left.{ }^{14} \mathrm{C}\right]$ leucine, when nascent ribosomal protein was labelled. Since it is established that puromycin promotes the release of incompleted nascent polypeptide from ribosomes (Nathans, 1964), the results described show that $\left[{ }^{14} \mathrm{C}\right]$ glucosaminelabelled nascent protein is associated with polyribosomes from rat liver. Initiation of the formation of the oligosaccharide moieties of glycoproteins must therefore occur while the nascent polypeptide is associated with the ribosome.

This conclusion is in agreement with that reached by Molnar \& Sy (1967), but is at variance with conclusions reached by other workers from studies with other tissues (Bouchilloux \& Cheftel, 1966;
Cheftel \& Bouchilloux, 1968; Hagopian, Bosmann \& Eylar, 1968; Swenson \& Kern, 1968). Since the addition of monosaccharides to polypeptides is determined by enzymes (Grebner, Hall \& Neufeld, 1966; Hagopian et al. 1968; McGuire \& Roseman, 1967), the initiation of monosaccharide attachment will depend on the intracellular location of these enzymes. If they are located in close proximity to the ribosomes the monosaccharides will be attached to the nascent protein, but if the enzymes are not located in the vicinity of the ribosomes attachment of sugars will only occur after the completed polypeptide has dissociated from the ribosome. Such a mechanism would account for the various conclusions reported.

Bouchilloux, S. \& Cheftel, C. (1966). Biochem. biophys. Res. Commun. 23, 205.

Cheftel, C. \& Bouchilloux, S. (1968). Biochim. biophys. Acta, 170, 15.

Grebner, E. E., Hall, C. W. \& Neufeld, E. F. (1966). Arch. Biochem. Biophys. 116, 391.

Hagopian, A., Bosmann, H. B. \& Eylar, E. H. (1968). Arch. Biochem. Biophys. 128, 387.

McGuire, E. J. \& Roseman, S. (1967). J. biol. Chem. 242, 3745.

Molnar, J., Robinson, G. B. \& Winzler, R. J. (1965). J. biol. Chem. 240, 1882.

Molnar, J. \& Sy, D. (1967). Biochemistry, 6, 1941.

Nathans, D. (1964). Fed. Proc. 23, 984.

Robinson, G. B. (1968). Biochem. J. 108, 275.

Robinson, G. B. (1969). FEBS Lett. 4, 190.

Swenson, R. M. \& Kern, M. (1968). Proc. nat. Acad. Sci., Wash., 59, 546.

Traut, R. R. \& Monro, R. E. (1964). J. molec. Biol. 10, 63. 